\title{
Correspondence
}

\section{"CRUDE COAL TAR IN DERMATOLOGY"}

To the Editor:-In White's article on "Crude Coal Tar in Dermatology," which appeared in the Archives for December, 1921, page 803, he states: "I believe that Brocq's introduction of this drug has constituted one of the greatest therapeutic contributions in modern times." Dind of Lausanne was the first to call attention to crude coal tar as a useful remedy in dermatologic practice (Le coal tar, mode d'application, resultats therapeutiques, Verhandl. d. deutsch. Dermat. Gesellsch., neunter Kongress gehalten zu Bern, Sept. 12-14, 1906, p. 377). Later Chajes, Brocq, Blaschko and others employed the preparation extensively. I read a paper on the subject "Coal Tar in Dermatology," in 1915, which was published in the Urologic and Cutaneous Review, vol. 20, No. 2, 1916, and that was, I believe, the first mention of crude coal tar in American medical literature.

J. W. Miller, M.D., Cincinnati. 